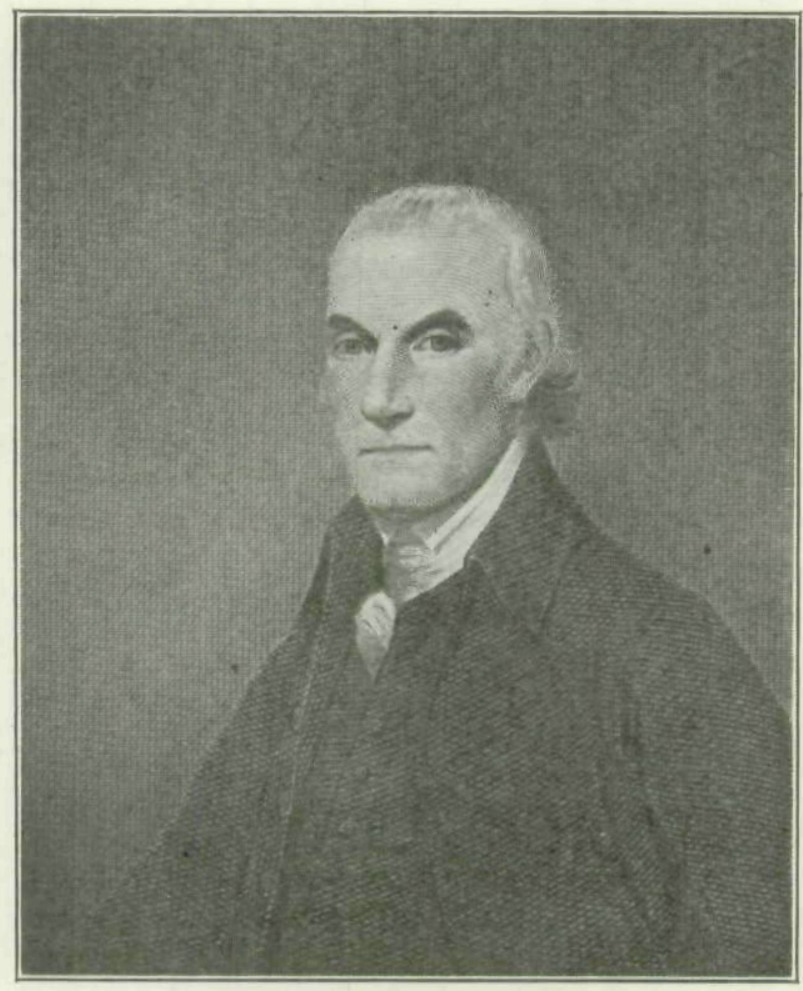

WILLIAM FLOYD

After whom Floyd County was named. 


\title{
FLOYD COUNTY NAMED FOR WILLIAM FLOYD
}

\author{
By Whliam H. Fleming
}

Hon. Phineas M. Casady who was a senator of this state in the Third and Fourth General Assemblies, was a member of the committee that put on the map the lines and names of about fifty counties then established, and was authority for the statement that the committee, in selecting names therefor, determined to name a number of the new creations in groups of three each in honor of characters of eminence, and an additional group of names of battle fields in the war with the neighboring republic of Mexico. One of these groups was composed of names of the signers of the Declaration of Independence; one of men noted in science; one of distinguished Europeans; one of men noted for zeal for Ireland in revolutionary periods; groups of Indian cognomens, etc. For the group of signers of the Declaration of Independence were chosen William Floyd, John Hancock, and Charles Carroll. The writer, who prepared the compilation for the combined census figures of the first sixty years of Iowa history, was under the impression that the county of Floyd was named in honor of Sergeant Floyd of the Lewis and Clark expedition, who perished during that expedition, and whose memory is perpetuated in a monument near Sioux City, where he died. Judge Casady, afterwards communicating the facts as to the naming of the new counties of 1851 , informed the writer hereof that Floyd County was named in honor of William Floyd who was the first from New York to sign the Declaration. This being the case, it is thought well to give to the public the facts in respect to that county's cognomen, and also relate something of the history of the patriot whose name the county bears.

William Floyd was born in Suffolk County, Long Island, New York, December 17, 1734. An ancestor, his great-grandfather, coming from the principality of Wales eighty years before, settled at Setauket, in the same county. There William Floyd lived and became interested in the colonial efforts for freeing the colonies from the oppression of the Imperial Government. In 1775 he was elected to the Continental Congress, where he re- 
mained for several years, being out of that body only about one year until after the war was over. The provincial congress of New York was slow in instructing its delegates to vote for independence, and Floyd and his colleagues were rather embarrassed in view of the fact that if they did not vote for the Declaration they would be in a sort of opposition to the Congress. But, when the trying time came, Mr. Floyd led the way among the New York delegates as signer.

A loyalist legislature had held to power in New York for several years; and it was not before a conviention was chosen by the people, in defiance of royal authority, that the colony declared for independence. New York was tryingly situated. Her seaport was likely to fall into the hands of the enemy, a British corps was already in possession of Staten Island, at the mouth of the great harbor, and a British army was threatening from Canada. But a convention chosen by freeholders, who felt they were in danger of losing their possessions should the rebellion fail, nevertheless declared for independence, and on July 9 New York joined the other colonies, where Floyd led the way in signing, followed by Philip Livingston, Francis Lewis, and Lewis Morris. It is said of him that in Congress, while not much of a speechmaker, he was a valuable member of the committee, being clear-headed and a man of strong character.

When the British made their first raid on Long Island he headed a company of militia and drove them off, but in the year of independence he and his family were driven across Long Island Sound and for several years he did not see the property nor derive benefit from it. "His house was used for cavalry barracks. He was made a state senator by the Senate, as the locality he was to represent was occupied by the enemy so that popular elections were not permitted, but he was afterward elected to the Senate by the regular voters, holding that position about five years. In 1786 he was made brigadier-general of the state militia. In 1787 he was chosen a member of the Council of Appointment, an organization peculiar to the state of New York under its first constitutions. It was composed of four senators chosen from as many districts by the Assembly, as the other house is designated in that state. He was a representative 
in the first Congress under the Constitution, but declined a reelection.

In 1795 he was the Republican candidate for lieutenant-governor, but was defeated by a Federalist, Stephen Van Rensselaer. About that time he removed to Oneida County. Living there, he was again elected to the State Senate from the western district. In 1800, 1804, and 1820 he was presidential elector, voting as such twice for Jefferson and once for Monroe.

On the anniversary of Independence Day in 1821, a century ago the present year, the people of Utica presented an affectionate and patriotic address to him to which he made this appropriate reply:

Gentlemen: The friendly and respectful address you present me in behalf of a number of my fellow-citizens, who are met together for the purpose of celebrating the independence of America, gives me pleasure, because it brings to my mind, that the measures which were pursued, and the firmness of those men who lived and were active in the Revolution, laid the foundation for that extensive happiness and prosperity which the inhabitants of the United States enjoy, beyond what is enjoyed by the people of any other country in the world. And it is a consolation to me to hope, that the same happiness and prosperity may be enjoyed by generations yet unborn. I am, with great respect, your obedient servant.

William Floyd.

One month later, August 4, 1821, General Floyd died at his home in Westernville, Oneida County, in the eighty-seventh year of his age. Excepting two of the committee that drafted the Declaration whose deaths on the fiftieth anniversary of the day afford one of the most marvelous coincidences in all history, and Charles Carroll, he was the last survivor of the signers of the great instrument.

An obituary notice of General Floyd said of him, "The character and conduct of the deceased were in conformity with the exalted station which it was his happiness to fill. He was loved, respected and revered by all who knew him. His conduct in private life was as commendable as his public works were glorious." . 
Copyright of Annals of Iowa is the property of State of Iowa, by \& through the State Historical Society of Iowa and its content may not be copied or emailed to multiple sites or posted to a listserv without the copyright holder's express written permission. However, users may print, download, or email articles for individual use. 